\title{
Neotropical mammal diversity and the Great American Biotic Interchange: spatial and temporal variation in South America's fossil record
}

\author{
Juan D. Carrillo ${ }^{1,2 *}$, Analía Forasiepi ${ }^{3}$, Carlos Jaramillo² and Marcelo R. Sánchez-Villagra ${ }^{1}$ \\ ${ }^{1}$ Paläontologisches Institut und Museum, University of Zurich, Zurich, Switzerland \\ ${ }^{2}$ Smithsonian Tropical Research Institute, Panama City, Panama \\ ${ }^{3}$ Instituto Argentino de Nivología, Glaciología y Ciencias Ambientales (IANIGLA), CCT-CONICET Mendoza, Mendoza, Argentina
}

\author{
Edited by: \\ James Edward Richardson, Royal \\ Botanic Garden Edinburgh, UK \\ Reviewed by: \\ William Daniel Gosling, University of \\ Amsterdam, Netherlands \\ Bruce D Patterson, Field Museum of \\ Natural History, USA \\ *Correspondence: \\ Juan D. Carrillo, Paläontologisches \\ Institut und Museum, University of \\ Zurich, Karl-Schmid-Strasse 4, 8006 \\ Zürich, Switzerland \\ e-mail: juan.carrillo@pim.uzh.ch
}

The vast mammal diversity of the Neotropics is the result of a long evolutionary history. During most of the Cenozoic, South America was an island continent with an endemic mammalian fauna. This isolation ceased during the late Neogene after the formation of the Isthmus of Panama, resulting in an event known as the Great American Biotic Interchange (GABI). In this study, we investigate biogeographic patterns in South America, just before or when the first immigrants are recorded and we review the temporal and geographical distribution of fossil mammals during the GABI. We performed a dissimilarity analysis which grouped the faunal assemblages according to their age and their geographic distribution. Our data support the differentiation between tropical and temperate assemblages in South America during the middle and late Miocene. The GABI begins during the late Miocene $(\sim 10-7 \mathrm{Ma})$ and the putative oldest migrations are recorded in the temperate region, where the number of GABI participants rapidly increases after $\sim 5 \mathrm{Ma}$ and this trend continues during the Pleistocene. A sampling bias toward higher latitudes and younger records challenges the study of the temporal and geographic patterns of the GABI.

Keywords: Miocene, Pliocene, biogeography, mammalia, South America

\section{INTRODUCTION}

The Neotropics [Neotropical region sensu lato of Morrone (2014)] supports an extremely large diversity of living mammals. Currently there are around 1500 recognized species which represent in the order of $30 \%$ of the total world mammal diversity. Included are endemic groups such as marsupials (opossums), xenarthrans (sloths, armadillos, and anteaters), caviomorph rodents (capybaras, spiny rats, chinchillas), platyrrhine monkeys, and phyllostomid bats (Patterson and Costa, 2012). The variety of biomes found in the Neotropics (lowland rainforest, savannas, mountain forest, scrublands, and deserts) could provide a partitioned environment enhancing species richness (Tews et al., 2004).

The current Neotropical mammal fauna is the result of a long evolutionary history. The Cenozoic $(66-0 \mathrm{Ma})$ in South America was characterized by long term geographical isolation with the evolution of an endemic fauna (Simpson, 1980). Sporadic dispersal events from other geographic areas interrupted this isolation introducing novel clades into South America including caviomorph rodents during the middle Eocene $(\sim 41 \mathrm{Ma})$ and platyrrhine monkeys during the late Oligocene $(\sim 26 \mathrm{Ma})$ (Pascual, 2006; Antoine et al., 2012; Croft, 2012; Goin et al., 2012). The isolation of South America's mammal fauna ceased by $\sim 10-7 \mathrm{Ma}$, when proximity, and then permanent connection was established with Central America. This connection initiated a massive faunal exchange between North America (NA) and South America (SA). This event is known as the Great American Biotic Interchange (GABI) (Simpson, 1980; Webb, 1985). The classic interpretation places the onset of the GABI by $\sim 3.0 \mathrm{Ma}$, with some early migrations during the late Miocene from SA to NA by $\sim 9 \mathrm{Ma}$ and from NA to SA by $\sim 7 \mathrm{Ma}$. Other studies using dated molecular phylogenies across a wide range of taxa indicate an important part of the interchange may have predated the permanent land connection by $\sim 3 \mathrm{Ma}$ (Koepfli et al., 2007; Cody et al., 2010; Eizirik et al., 2010; Eizirik, 2012). The core of the GABI is composed by a series of major migration "waves" during the Pliocene-Pleistocene (2.5-0.012 Ma) (Webb, 2006; Woodburne, 2010). Recently, several NA mammals have been reported from the late Miocene deposits, $\sim 10 \mathrm{Ma}$, within the Amazon basin. These include a dromomerycine artiodactyl, gomphotheres, peccaries, and tapirs which suggest a more intense earlier connection (Campbell et al., 2000, 2010; Frailey and Campbell, 2012; Prothero et al., 2014). However, the taxonomy and age of some of these fossils have been questioned (Alberdi et al., 2004; Lucas and Alvarado, 2010; Lucas, 2013). In Amazonia, Pleistocene terraces are built from older Cenozoic deposits (Latrubesse et al., 1997), resulting in non-contemporaneous associations (Cozzuol, 2006). Even with these concerns in mind, in the last decades the presence of northern forms in South America is becoming better understood. 
During the late Miocene (11.6-5.3 Ma) and early Pliocene (5.3-3.6 Ma), the GABI was taxonomically balanced, as predicted by the MacArthur-Wilson species equilibrium hypothesis, with similar number of NA and SA families participating in the interchange (Webb, 1976; Marshall et al., 1982). During the Pleistocene, NA mammals appeared to have diversified exponentially in SA, resulting in an overall prevalence of NA over SA-derived mammals. This could be the result of competitive displacement (Webb, 1976, 1991; Marshall et al., 1982), but this has not been subjected to rigorous analyses. In contrast, ecological replacement has been demonstrated for extinct metatherians and placental carnivores (Prevosti et al., 2013).

Vrba (1992) analyzed the GABI in the context of the "habitat theory" (i.e., physical environmental changes are the main drivers of "distribution drift") and highlighted the importance of environmental changes over biotic interactions as the major cause of the biotic turnover. Webb (1991) proposed that the Pleistocene glaciations and the widespread development of savannas in the Neotropics facilitated dispersals during the GABI of savannaadapted mammals. Woodburne (2010) agreed with Webb's model and related the pulses of faunistic movements to the glaciations and sea level changes of the Pliocene and Pleistocene. However, most recent evidence does not support the widespread expansion of savannas in the tropics during glacial times (Behling et al., 2010). The GABI was dynamic with bidirectional migrations (Carlini et al., 2008b; Castro et al., 2014) and with reciprocal exchanges within a single lineage (e.g., procyonids; Baskin, 1989; Forasiepi et al., 2014; and felids; Prevosti, 2006).

Potential biogeographic barriers or corridors along with environmental changes controlled patterns of movements (Webb, 1991; Woodburne, 2010). The Andes are currently an important biogeographic feature in South America extending for about $8000 \mathrm{~km}$ from Venezuela to Argentina, reaching average heights of about 4000 masl and maximum elevations up to 7000 masl (Ramos, 1999). The present day elevations of the northern and the north central Andes (north of $20^{\circ} \mathrm{S}$ ) were reached during or soon after the late Miocene (Mora et al., 2009) and may have constituted a colonization corridor during the GABI (Patterson et al., 2012 and references therein).

A full understanding of the GABI is difficult because of the difference in fossil sampling between low and high latitudes (Figure 1). Even with the major recent advances in Neotropical paleontology (Kay et al., 1997; Campbell, 2004; MacFadden, 2006; Sánchez-Villagra et al., 2010; Antoine et al., 2012), our knowledge of this large portion of territory that comprises the neotropics, twice the size of Europe and almost as large as North America is scarce (Croft, 2012).

In this contribution, we investigate biogeographic patterns for the middle and late Miocene (15.9-5.3 Ma) in SA at the initiation of the GABI. We review the temporal and geographical distribution of fossil mammals during the GABI and discuss the special significance of the fossil record from northern SA to understand the patterns and dynamics of the interchange.

\section{MATERIALS AND METHODS}

Species lists from several middle and late Miocene-Pliocene mammal associations (La Venta, Fitzcarrald, Quebrada Honda,

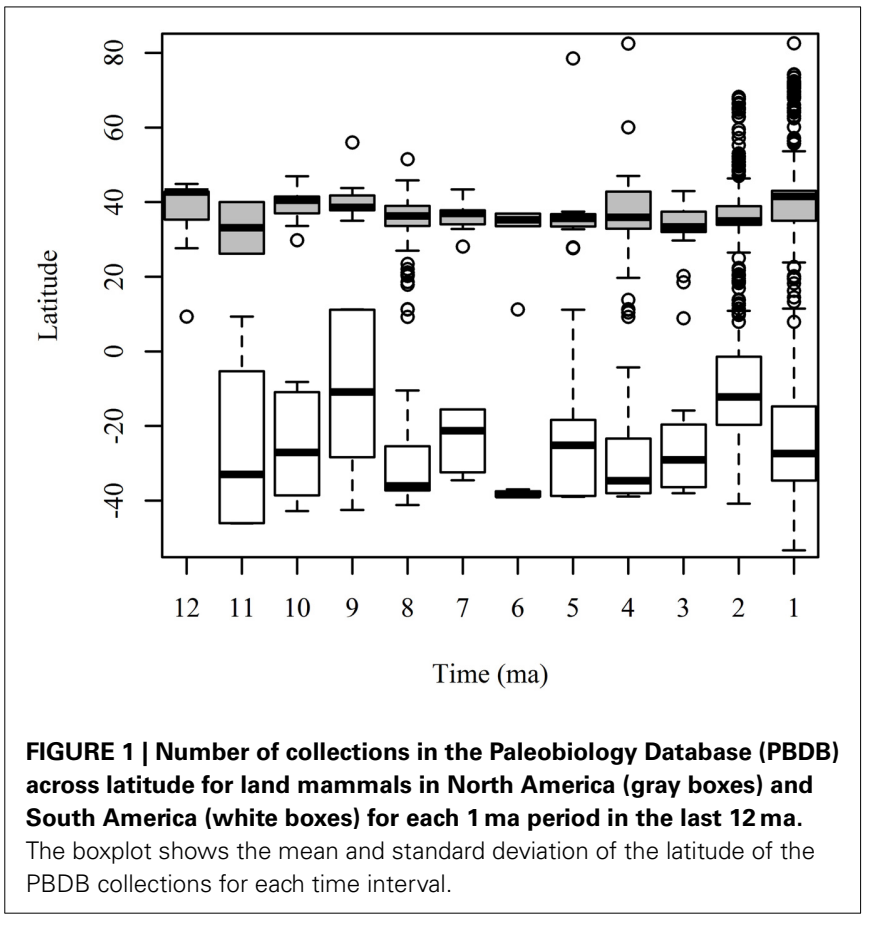

Collon Curá, Urumaco, Acre, Mesopotamian, Cerro Azul, Chiquimil, Andalhuala, Monte Hermoso, Inchasi and Uquía) were compiled from several sources (Goin et al., 2000; Cozzuol, 2006; Reguero and Candela, 2011; Brandoni, 2013; Tomassini et al., 2013; Tejada-Lara et al., in press) and other references available in the Paleobiology Database (PBDB) (Alroy, 2013), to which we added 450 references with records of Neogene fossil mammals from the Americas (Figures 2, 3; Supplementary Material 1-2). We obtained latitude and paleolatitude from each locality from the PBDB (Table 1) and estimated the distance in $\mathrm{km}$ among localities using Google Earth. Localities were coded for presence/absence at the generic level (Supplementary Table 1). The biochronology refers to the South American Land Mammal Ages (SALMA) and the calibration of the boundaries of Tomassini et al. (2013, modified from Cione et al., 2007) and Cione and Tonni (1999, 2001). Genera were used as taxonomic unit (including taxonomic identifications with $c f$. and aff. qualifiers). Lower taxonomical levels are still unresolved for several localities and data are incomparable.

We analyzed closely contemporaneous fossil mammal associations from SA using the Bray-Curtis binary dissimilarity index. This reaches a maximum value of 1 when there are no shared taxa between the two compared communities. The Vegan package (Okasanen et al., 2013) was used to perform a cluster analysis with average grouping method and a Nonmetric Multidimensional Scaling (NMDS) set to two dimensions (axes) and 1000 runs. We compared tropical and temperate Miocene localities, and in order to account for differences in the sample size, we set the number of taxa equal to the assemblage with the lowest richness within the subgroup and calculate Bray-Curtis dissimilarity by resampling with replacement 1000 times all the localities. The Vegan package was used to obtain genera accumulation curves for 


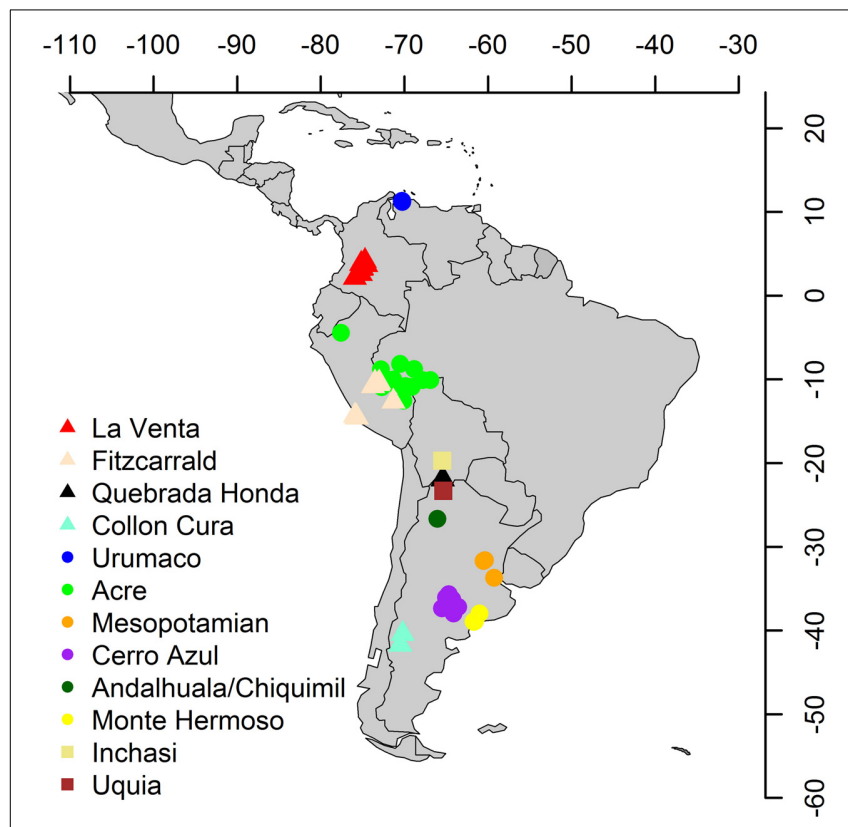

FIGURE 2 | Middle and late Miocene - Pliocene main fossil sites for land mammals in South America. Triangles, middle Miocene; circles, late Miocene; squares, Pliocene.

tropical assemblages, using the random method. All analyses were performed in R (R Core Team, 2013).

We obtained records for late Miocene to late Pliocene land mammals for NA and SA from the PBDB. We classified each genus as North or South American if the taxon or its ancestor were in either NA or SA before $10 \mathrm{Ma}$. We compared the geographic distribution (tropical vs. temperate) and time of first appearance datum (FAD) of GABI migrants in the continent (Supplementary Material 3 and Supplementary Table 2). In order to account for the age uncertainty of each FAD, we generate 1000 different random values between the maximal and minimal age estimate and calculate the mean and standard deviation of the age estimate for each record.

\section{STUDY SITES}

We selected faunal associations from the tropical and temperate regions of South America which all together span from the middle Miocene $(\sim 15 \mathrm{Ma})$ to the late Pliocene $(\sim 2 \mathrm{Ma})$, a critical time period for the GABI. The study sites cover a wide latitudinal gradient across the continent (Table $\mathbf{1}$ ).

\section{La Venta}

La Venta is one of the best-studied fossil assemblages from the Neotropics and among vertebrates includes freshwater fishes, crocodiles, turtles and different mammal clades (Kay et al., 1997). These come from the Honda Group in the central Magdalena valley, Colombia (Figure 2). Its age is constrained by radiometric and paleomagnetic data. The assemblage of La Venta served as the basis for defining the Laventan SALMA (middle Miocene, 13.5-11.8 Ma) (Madden et al., 1997).

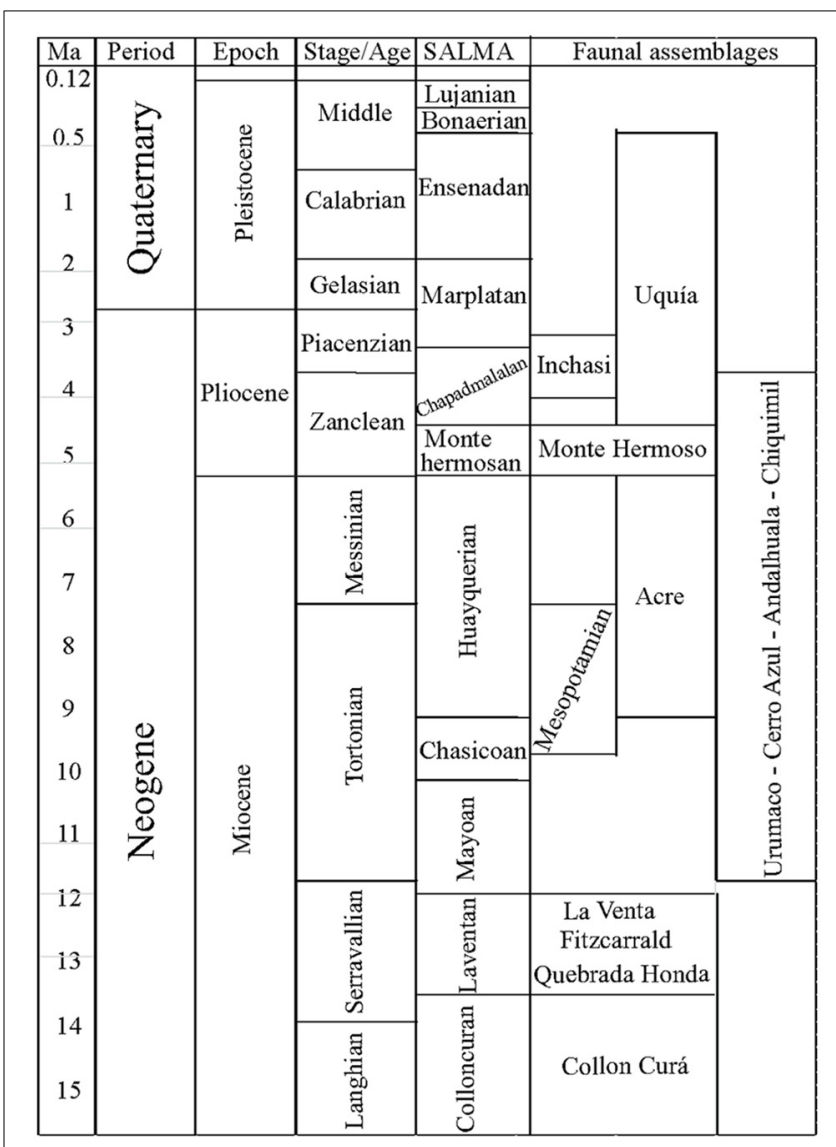

FIGURE 3 | Chronostratigraphy, South American Land Mammal Ages (SALMAs) and temporal distribution of the faunal assemblages discussed in the text. Colloncuran:15.7-14 Ma (Madden et al., 1997) Laventan: 13.5-11.8 Ma. (Madden et al., 1997); Mayoan: 11.8-10 Ma. (Flynn and Swisher, 1995); Chasicoan: 10- 8.5 (Flynn and Swisher, 1995); Huayquerian = 8.5-5.28 Ma. Lower age following (Cione and Tonni, 2001; Reguero and Candela, 2011) and upper age following (Tomassini et al., 2013); Montehermosan =5.28 -4.5/5.0 Ma. (Tomassini et al., 2013); Chapadmalalan $=4.5 / 5.0-3.3$ (Tomassini et al., 2013); Marplatan = $3.3-$ $\sim 2.0 \mathrm{Ma}$. Lower age following (Tomassini et al., 2013) and upper age following (Cione and Tonni, 1999; Cione et al., 2007); Ensenadan = 2.0-<0.78(0.5?) Ma. (Cione and Tonni, 1999; Cione et al., 2007); Bonaerian $=<0.78(0.5$ ?) $-0.13 \mathrm{Ma}$. (Cione and Tonni, 1999); Lujanian = 0.13-0.08 Ma (Cione and Tonni, 1999).

\section{Fitzcarrald}

The localities of the Fitzcarrald assemblage are found along the Inuya and Mapuya rivers in the Amazon of Peru (Figure 2) from the Ipururo Formation, interpreted as middle Miocene (Laventan Age) (Antoine et al., 2007; Tejada-Lara et al., in press). The vertebrate assemblage includes fishes, turtles, crocodiles, snakes and 24 mammalian taxa (Negri et al., 2010; Tejada-Lara et al., in press).

\section{Quebrada Honda}

Quebrada Honda is located in southern Bolivia at $\sim 21^{\circ} \mathrm{S}$ latitude, $20 \mathrm{~km}$ north of the Argentine frontier and at an elevation of about $3500 \mathrm{~m}$ (Figure 2). The fossil-bearing deposits crop out in the valley of the Honda River and its tributaries. Paleomagnetic and radioisotopic data provide an extrapolated age of 13-12.7 Ma for 
Table 1 | Modern and ancient latitude and elevation of the faunal assemblages used in this study.

\begin{tabular}{lllll}
\hline Faunal association & Latitude & Paleolatitude & Elevation & Paleoelevation \\
\hline La Venta & $\sim 3^{\circ} \mathrm{N}$ & $\sim 26^{\circ} \mathrm{N}$ & $\sim 380 \mathrm{~m}$ & "Lowland" \\
Fitzcarrald & $\sim 10.5^{\circ} \mathrm{S}$ & $\sim 12^{\circ} \mathrm{S}$ & $<300 \mathrm{~m}$ & "Lowland" \\
Quebrada Honda & $\sim 22^{\circ} \mathrm{S}$ & $\sim 22^{\circ} \mathrm{S}$ & $\sim 3500 \mathrm{~m}$ & $\sim 2600 \pm 600 \mathrm{~m}$ \\
Collón Curá & $\sim 40^{\circ} \mathrm{S}$ & $\sim 41^{\circ} \mathrm{S}$ & $\sim 800 \mathrm{~m}$ & Tropical \\
Urumaco & $\sim 11^{\circ} \mathrm{N}$ & $\sim 11^{\circ} \mathrm{N}$ & $<100 \mathrm{~m}$ & Temperate \\
Acre & $\sim 10^{\circ} \mathrm{S}$ & $\sim 10.5^{\circ} \mathrm{S}$ & $<300 \mathrm{~m}$ & Temperate \\
Mesopotamian & $\sim 32^{\circ} \mathrm{S}$ & $\sim 32^{\circ} \mathrm{S}$ & $<100 \mathrm{~m}$ & "Lowland" \\
Cerro Azul & $\sim 37^{\circ} \mathrm{S}$ & $\sim 37^{\circ} \mathrm{S}$ & "Lowland" \\
Chiquimil & $\sim 27^{\circ} \mathrm{S}$ & $\sim 27^{\circ} \mathrm{S}$ & "Lowland" \\
Andalhuala & $\sim 27^{\circ} \mathrm{S}$ & $\sim 27^{\circ} \mathrm{S}$ & $150 \mathrm{~m}-2500 \mathrm{~m}$ & $?$ \\
Monte Hermoso & $\sim 38^{\circ} \mathrm{S}$ & $\sim 38^{\circ} \mathrm{S}$ & $1000-2500 \mathrm{~m}$ & Tropical \\
Inchasi & $\sim 19^{\circ} \mathrm{S}$ & $\sim 20^{\circ} \mathrm{S}$ & $<100 \mathrm{~m}$ & Temperate \\
Uquía & $\sim 23^{\circ} \mathrm{S}$ & $\sim 23^{\circ} \mathrm{S}$ & $\sim 3220 \mathrm{~m}$ & Temperate \\
\hline
\end{tabular}

the fossil bearing beds (MacFadden et al., 1990). Multiple proxies to estimate paleoelevation of the Central Andean Altiplano have yielded values between 1000 and $2000 \mathrm{~m}$ for the middle Miocene (Garzione et al., 2008); however, a most recent study using clumped isotope thermometry on paleosol carbonates inferred an earlier uplift for the Altiplano, with Quebrada Honda at about $2600 \pm 600 \mathrm{~m}$ and a mean annual temperature of $\sim 9 \pm 5^{\circ} \mathrm{C}$ (Garzione et al., 2014). The assemblage includes about 30 mammals representing metatherians, xenarthrans, rodents, astrapotheres, litopterns and notoungulates and correspond to the Laventan SALMA (Croft, 2007).

\section{Collón Curá}

The Collón Curá Formation is largely exposed at the west of Nord-Patagonian Massif (Neuquén and Río Negro provinces, and Norwest Chubut Province). The rich vertebrate association is represented by reptiles, birds, and principally mammals: metatherians, xenarthrans, rodents, notoungulates, litopterns, and astrapotheres (Kramarz et al., 2011). The fossil mammals collected in the vicinities of the Collón Curá river by Santiago Roth in the late 19th Century are the basis for the definition of the Colloncuran SALMA, although a critical review of most of the findings is still pending. Several radiometric dates for the Collón Curá Formation indicate ages between 15.5 and $10 \mathrm{Ma}$ for the vertebrate association (e.g., Rabassa, 1974, 1978; Marshall et al., 1977; Bondesio et al., 1980; Mazzoni and Benvenuto, 1990; Madden et al., 1997).

\section{Urumaco}

The Urumaco sequence is found in the Falcón State in northwestern Venezuela (Figure 2). It includes the Querales, Socorro, Urumaco, Codore and San Gregorio formations, which together span from the middle Miocene to late Pliocene (Quiroz and Jaramillo, 2010). The Urumaco sequence shows a high diversity of crocodilians (Scheyer et al., 2013) and xenarthrans (Carlini et al., 2006a,b, 2008a,c). We focus our analysis on the Urumaco Formation. Linares (2004), on the basis of a mammal list of undescribed material suggested a middle to late Miocene age. Until a detail taxonomic revision is conducted, the biostratigraphic correlation of the Urumaco association remains tentative.

\section{Acre}

The Acre region in the southwestern Amazonia includes several fossiliferous localities which would represent different time intervals considering the geological and palinological evidence (Cozzuol, 2006). Fossil vertebrates come from the Solimões Formation of the state of Acre, Brazil and Peruvian and Bolivian localities from the Madre de Dios Formation (Negri et al., 2010) (Figure 2). The vertebrate assemblage is very diverse and includes fishes, snakes, lizards, birds, turtles, crocodiles, and mammals including whales, dolphins, manatees and a diverse assemblage of terrestrial forms. The Acre mammal assemblage has been referred to late Miocene, Huayquerian SALMA (Cozzuol, 2006; Ribeiro et al., 2013) or included also in the Pliocene, Montehermosan SALMA (Cozzuol, 2006). Campbell et al. (2001) reported ${ }^{40} \mathrm{~A} /{ }^{39} \mathrm{~A}$ dates of $9.01 \pm 0.28 \mathrm{Ma}$ for the base of the Madre de Dios Formation and 3.12 \pm 0.02 Ma near the top.

\section{Mesopotamian}

The continental mammals of the Mesopotamian assemblage come from the lower levels of the Ituzaingó Formation, which crops out along the cliffs of the Paraná River in Corrientes and Entre Ríos provinces, north-east Argentina (Figure 2). The vertebrate assemblage is rich and includes fishes, crocodiles, birds and mammals (Cione et al., 2000; Brandoni and Noriega, 2013). It differs taxonomically from other associations in Argentina at the same latitudes and this was explained by a southern extension of the northern realm (Cozzuol, 2006). The age of the Mesopotamian assemblage has been largely debated (Cione et al., 2000 and references therein); it is currently assigned to the late Miocene, Huayquerian SALMA (Cione et al., 2000) or also extended into the Chasicoan SALMA (Brandoni, 2013; Brunetto et al., 2013). The dating of 9.47 Ma for the upper levels of the lower Paraná Formation (Pérez, 2013) represents a maximum limit for the Mesopotamian assemblage. 


\section{Cerro Azul}

Several localities in central east Argentina (La Pampa and Buenos Aires provinces) have provided abundant fossil vertebrates from the Cerro Azul and Epecuén formations which are considered geologically correlated (Goin et al., 2000). This assemblage includes reptiles, birds and a rich mammal association. These units are assigned to the late Miocene, Huayquerian SALMA (Goin et al., 2000; Montalvo et al., 2008; Verzi and Montalvo, 2008; Verzi et al., 2011) on the basis of mammal biostratigraphy. This association is currently the most complete list for this age (Goin et al., 2000). The possibility of extension into the late Pliocene cannot be discarded for some localities assigned to the Cerro Azul Formation (Prevosti and Pardiñas, 2009).

\section{Chiquimil}

The Chiquimil Formation is exposed in north-west Argentina (Catamarca Province) and is divided in three members. The Chiquimil A (Riggs and Patterson, 1939; Marshall and Patterson, 1981) or El Jarillal Member (Herbst et al., 2000; Reguero and Candela, 2011) provided a rich fossil record. The mammalian association has been assigned to the late Miocene, Huayquerian SALMA (Reguero and Candela, 2011). A dating in the middle section of the Chiquimil Formation indicated $\sim 6.68 \mathrm{Ma}$ (Marshall and Patterson, 1981).

\section{Andalhuala}

The Andalhuala Formation is exposed in the Santa María Valley in north-west Argentina (Catamarca Province). This is a classical fossiliferous unit of the South American Neogene with abundant and diverse fossil remains, including plants, invertebrates, and vertebrates (Riggs and Patterson, 1939; Marshall and Patterson, 1981). Basal levels of the Andalhuala Formation have been dated to $\sim 7.14 \mathrm{Ma}$ (Latorre et al., 1997 ) and $\sim 6.02 \mathrm{Ma}$ (Marshall and Patterson, 1981) while a tuff sample close to the upper part of the sequence was dated to $\sim 3.53 \mathrm{Ma}$ (Bossi et al., 1993). The mammal association has been referred to the MontehermosanChapadmalalan SALMAs (Reguero and Candela, 2011).

\section{Monte Hermoso}

The Monte Hermoso Formation is exposed in the Atlantic coast at the south west of Buenos Aires Province, Argentina. This unit has provided fishes, anurans, reptiles, birds, and a diverse mammal association. Recent biostratigraphic and biochronological analyses (Tomassini and Montalvo, 2013; Tomassini et al., 2013) have recognized a single biozone (the Eumysops laeviplicatus Range Zone) in the Montehermosan Formation which is the base for the Montehermosan SALMA. The Montehermosan was restricted to the early Pliocene between $<5.28$ and $4.5 / 5.0 \mathrm{Ma}$ by considering the dating of 5.28 Ma in levels with Huayquerian mammals and paleomagnetic correlations in the upper Chapadmalal Formation (Tomassini et al., 2013).

\section{Inchasi}

The locality of Inchasi is found in the eastern cordillera in the department of Potosí, Bolivia at an elevation of about 3220 masl and $\sim 19^{\circ} \mathrm{S}$ latitude (Figure 2). The mammal assemblage includes 10 mammals, representing xenarthra, rodentia, and native ungulates (Litopterna and Notoungulata) (Anaya and MacFadden,
1995). Paleomagnetic analysis indicates an age of about 43.3 Ma. The analysis of the mammal association first suggested Montehermosan and/or Chapadmalalan ages (MacFadden et al., 1993). A later revision (Cione and Tonni, 1996) correlated Inchasi with the Chapadmalalan, although probably older than the classical Chapalmalalan sections at the Atlantic coast.

\section{Uquía}

The Uquía Formation crops out in the Quebrada de Humahuaca, Jujuy province, north western Argentina at an elevation of $\sim 2800$ masl and $\sim 23^{\circ} \mathrm{S}$ latitude (Figure 2). The Uquía Formation is divided in three units: the Lower Unit was assigned to the late Chapadmalalan, the Middle Unit to the Marplatan (Vorhuean, Sanandresian), and the Upper Unit to the Ensenadan (Reguero et al., 2007; Reguero and Candela, 2011). ${ }^{40} \mathrm{~K}-{ }^{40} \mathrm{Ar}$ data from a volcanic tuff ("Dacitic tuff") in the Lower Unit provided $~ 3.0$ Ma. Another tuff (U1) dated as $2.5 \mathrm{Ma}$ is the boundary between the Middle and Upper Unit. The geological and paleontological evidence suggested that during the late Pliocene the area was a wide intermountain valley at about 1700-1400 masl (Reguero et al., 2007).

\section{RESULTS}

MIDDLE AND LATE MIOCENE-PLIOCENE MAMMAL FAUNAS FROM SA

In the NMDS analysis (stress value $=0.083$ ), the analyzed South American localities are primarily grouped by age and secondarily by geographic position (Figure 4A). The NMDS1 clearly separates middle Miocene, late Miocene and Pliocene localities and for the middle and late Miocene assemblages, the NMDS2 separates tropical from temperate localities. For the middle Miocene (Colloncuran, Laventan), the cluster analysis separates the tropical assemblages of La Venta $\left(\sim 2.6^{\circ} \mathrm{N}\right.$ paleolatitude) and Fitzcarrald $\left(\sim 12.5^{\circ} \mathrm{S}\right.$ paleolatitude) from the southern Collón Curá $\left(\sim 41.3^{\circ} \mathrm{S}\right.$ paleolatitude) and Quebrada Honda $\left(\sim 22.3^{\circ} \mathrm{S}\right.$ paleolatitude). For the late Miocene (HuayquerianMontehermosan), Urumaco $\left(\sim 10.9^{\circ} \mathrm{N}\right.$ paleolatitude $)$ appears outside the groups formed by Acre $\left(\sim 10.5^{\circ} \mathrm{S}\right.$ paleolatitude) and Mesopotamian $\left(\sim 32.5^{\circ} \mathrm{S}\right.$ paleolatitude), another cluster includes the Argentinean assemblages of Andalhuala $\left(\sim 26.8^{\circ} \mathrm{S}\right.$ paleolatitude), Chiquimil ( $27.0^{\circ} \mathrm{S}$ paleolatitude), Cerro Azul $\left(\sim 37.0^{\circ} \mathrm{S}\right.$ paleolatitude), and Monte Hermoso ( $\sim 38.9^{\circ} \mathrm{S}$ paleolatitude). Finally, the early Pliocene (Chapadmalalan- Marplatan) temperate associations from Inchasi $\left(\sim 19.9^{\circ} \mathrm{S}\right.$ paleolatitude) and Uquía $\left(\sim 23.4^{\circ} \mathrm{S}\right.$ paleolatitude) cluster together, although there are no tropical assemblages to compare with. If we compare only faunal assemblages from the same time period (middle Miocene, late Miocene and Pliocene), there is a positive relationship between the Bray-Curtis dissimilarity and the distance of each pair of assemblages studied (Figure 4B).

The Bray-Curtis dissimilarity values with resampling calculated for the tropical, temperate and tropical vs. temperate assemblages for the middle and late Miocene shows that all the assemblages are very different (Figure 4C). The Bray-Curtis dissimilarity between middle Miocene tropical (La Venta and Fitzcarrald) and temperate (Quebrada Honda and Collón Curá) assemblages compared to the dissimilarity between tropical vs. temperate are found to be statistically significant. Dissimilarity 

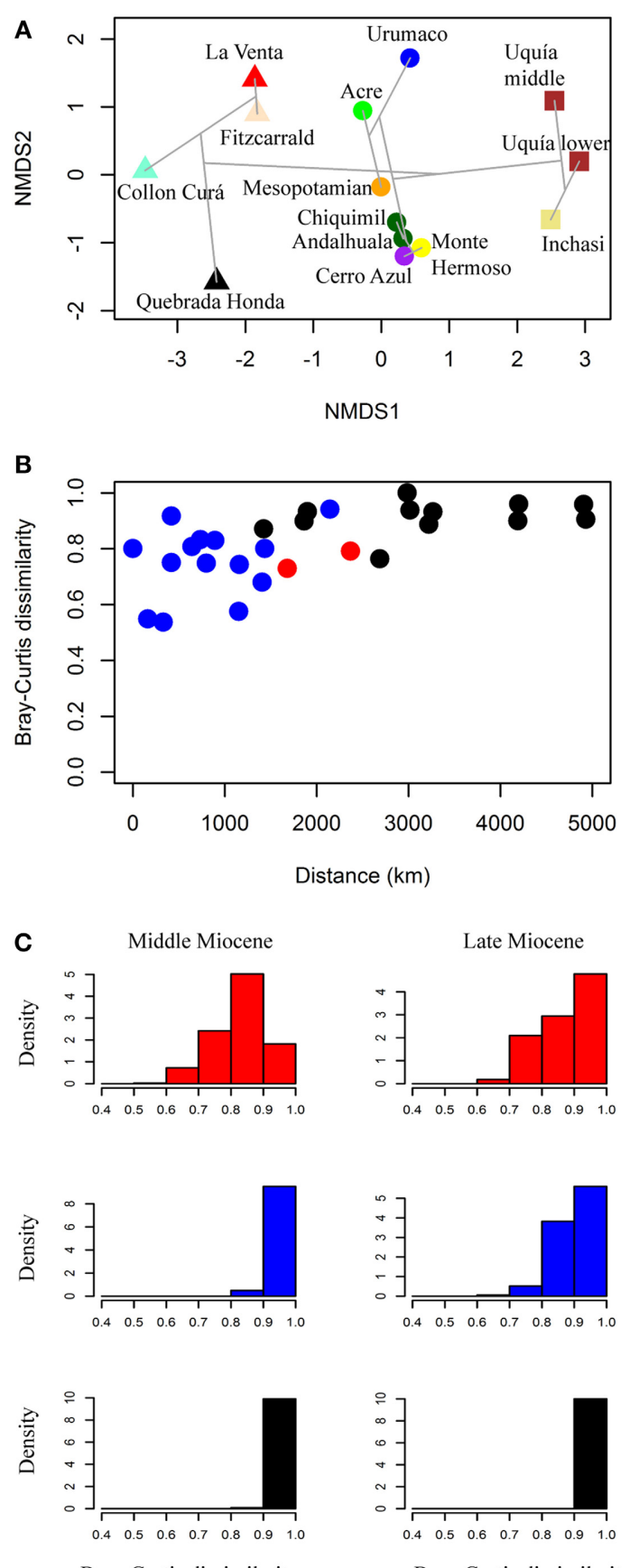

Bray-Curtis dissimilarity

Bray-Curtis dissimilarity

FIGURE 4 | (A) NMDS plot of the faunal associations using Bray-Curtis dissimilarity; triangles, middle Miocene; circles, late Miocene; squares, Pliocene. The gray lines show the clustering result. (B) Bray-Curtis dissimilarity relationship with distance in $\mathrm{km}$, between each locality pair. We include only localities pairs which are within the same time interval (middle Miocene, late Miocene, Pliocene), red, tropical-tropical pair; blue, temperate-temperate pair; black, tropical-temperate pair. (C) Density histograms of the Bray-Curtis dissimilarity values among the different faunal associations analyzed for the middle and late Miocene, red, only tropical faunas, blue, only temperate faunas, black, tropical vs. temperate faunas.

values of middle Miocene tropical $($ mean $=0.830)$ are lower than middle Miocene tropical vs. temperate (mean =0.956) (MannWhitney $\mathrm{U}, p<2.2 \mathrm{e}-16)$; whereas middle Miocene temperate dissimilarity (mean $=0.964$ ) is higher than middle Miocene tropical vs. temperate dissimilarity (Mann-Whitney $\mathrm{U}, p \leq 2.87$ e-15). For the late Miocene, dissimilarity of tropical assemblages (Acre and Urumaco) is lower (mean $=0.873$ ) than tropical vs. temperate $($ mean $=0.969$ ) (Mann-Whitney $\mathrm{U}, p<2.2 \mathrm{e}$ 16). We also found difference between temperate assemblages (Mesopotamian, Chiquimil, Andalhuala, Cerro Azul, and Monte Hermoso; mean $=0.899$ ) and tropical vs. temperate dissimilarity (Mann Whitney U, $p<2.2 \mathrm{e}-16$ ).

The number of PBDB collections was used to generate accumulation curves for the tropical assemblage (Figure 5). Each collection represents a geographic and stratigraphic point where the fossils have been found and provide a good proxy for sampling effort. We excluded from the analysis the Acre collection with unknown stratigraphic provenance. The accumulation curves show that generic richness for tropical assemblages is underestimated, even for the better known assemblage of La Venta.

\section{TEMPORAL AND SPATIAL DISTRIBUTION PATTERNS OF GABI}

The cumulative first appearance datum (FAD) of non-native taxa for both NA and SA continents (Figure 6A, Supplementary Table 2) shows that first migrations are recorded in the temperate region (cumulative $\mathrm{FAD}$ mean $=2$ by $10 \mathrm{Ma}$ ), represented by the ground sloths Thinobadistes (Mylodontidae) and Pliometanastes (Megalonychidae) recorded at McGehee Farm, Florida (Hirschfeld and Webb, 1968; Webb, 1989). During the late Miocene (12-5 Ma), the number of FAD is similar between the tropics (cumulative FAD mean $=6$ by $5 \mathrm{Ma}$ ) and temperate (cumulative FAD mean $=7$ by $5 \mathrm{Ma}$ ). In the tropics, the oldest records of migrants are those from the Acre region in Peru (Campbell et al., 2010; Prothero et al., 2014) of disputable age (Alberdi et al., 2004; Lucas and Alvarado, 2010; Lucas, 2013). During the Pliocene (between 3 and $4 \mathrm{Ma}$ ) there is an increase in the number of FAD at higher latitudes (cumulative FAD mean $=$

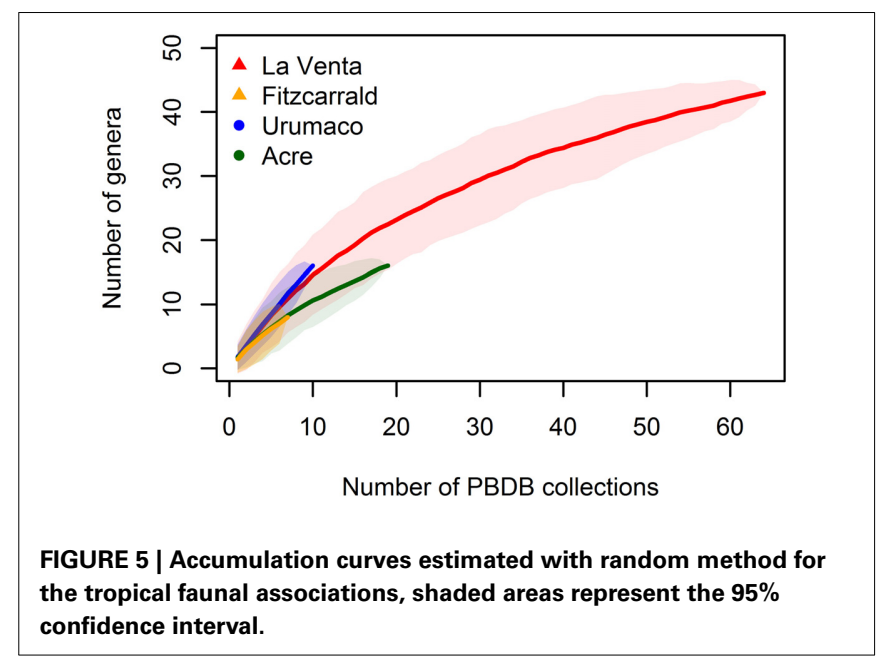



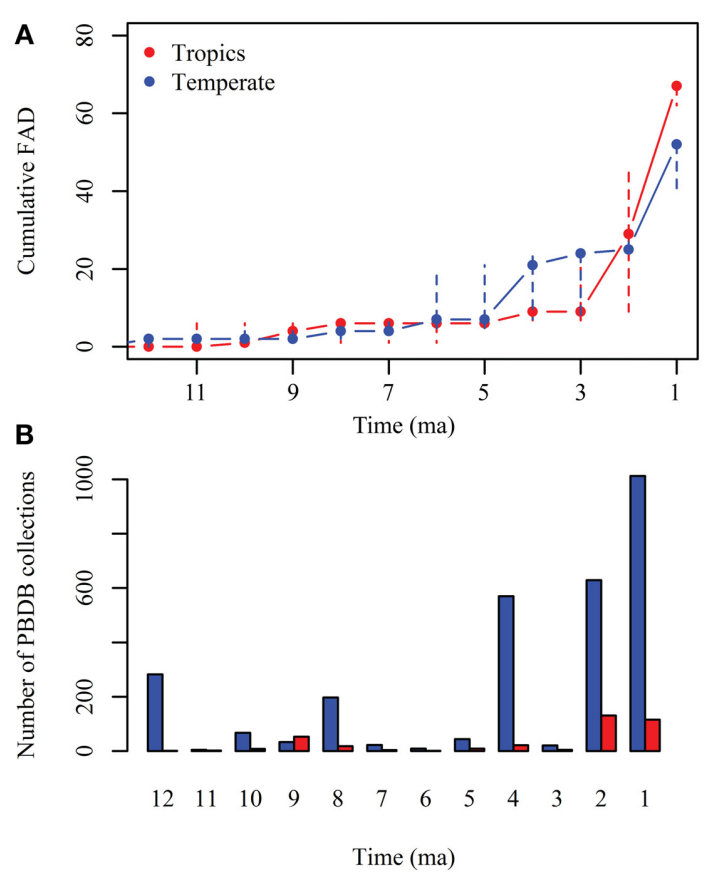

FIGURE 6 | (A) Cumulative first appearance datum (FAD) of GABI participants in North and South America for each million year since $12 \mathrm{Ma}$; red, FADs record in the tropics; blue, FADs record in the temperate regions. Solid circles represent the mean and dashed lines the standard deviation. (B) Number of collections with records of land mammals in the Paleobiology Database (PBDB) for each million year since $12 \mathrm{Ma}$; red, collections in the tropics; blue $=$ collections in the temperate region.

21 ), but this is not recorded in the tropics (cumulative FAD mean $=9)$. Finally, during the Pleistocene $(2-1 \mathrm{Ma}$ ) a higher number of FADs are recorded in tropical and temperate regions. Most of the collections in the PBDB with records of land mammals in the Americas are in the temperate region and are younger than $4 \mathrm{Ma}$ (Figure 6B).

\section{DISCUSSION}

\section{MIDDLE AND LATE MIOCENE-PLIOCENE MAMMAL FAUNAS FROM SA}

The NMDS1 shows that a strong temporal component establishes the dissimilarity relationships among the faunas. In addition, an important influence of the geographic position is reflected in the distribution of the faunas along the NMDS2 axis. There is a positive relationship between the Bray-Curtis dissimilarity values and the distance between faunas (Figures 4 A,B).

For the middle Miocene, Colloncuran-Laventan faunal associations, a differentiation between the tropical assemblages of $\mathrm{La}$ Venta and Fitzcarrald, and the southern Quebrada Honda and Collón Curá was observed (Figure 4A). The middle latitude fauna Quebrada Honda appears unique, although it is closer to the slightly older and temperate Collón Curá than to the contemporaneous tropical faunas of La Venta and Fitzcarrald (Croft, 2007; Tejada-Lara et al., in press). The reconstructed paleoenvironment for the middle Miocene Monkey Beds assemblage at La Venta considered an estimated annual rainfall between 1500 and $2000 \mathrm{~mm}$ using diet, locomotion and body size indices of the mammal community (Kay and Madden, 1997a,b).

For the late Miocene assemblages, the NMDS indicates a high dissimilarity between the tropical faunas of Urumaco and Acre. For the Urumaco mammal assemblage, xenarthrans and rodents are the most conspicuous elements, but further studies on other clades promise to document a higher diversity than currently recognized. The temperate assemblages of Chiquimil, Andalhuala, Cerro Azul, and Monte Hermoso cluster together and the Mesopotamian is between this group and Acre (Figure 4A).

After taking into account the differences in sample size, we found that the dissimilarity values of tropical assemblages ( mean $=0.830$ for middle Miocene, and mean $=0.879$ for late Miocene) and late Miocene temperate assemblages (mean = 0.899 for late Miocene) are lower than the values for tropical vs. temperate assemblages (mean $=0.956$ for middle Miocene and mean $=0.969$ for late Miocene) (Figure 4C). Consequently, the Bray-Curtis dissimilarity between faunas of the same age and biome is lower than between faunas of different biomes (tropical vs. temperate); although, the mean dissimilarity values in all cases are high $(>0.8)$.

As shown by the accumulation curves (Figure 5), the generic richness of the tropical assemblages studied are underestimated. A more comprehensive knowledge of tropical faunas is needed to better understand the paleodiversity patterns and paleobiogeography in the new world.

\section{TEMPORAL AND SPATIAL DISTRIBUTION PATTERNS OF GABI}

The cumulative FAD across time of GABI participants in each continent shows that the GABI was a gradual process that began in the late Miocene $(\sim 10 \mathrm{ma})$ (Figure 6A). The early phase of GABI (pre GABI sensu Woodburne, 2010) is characterized by a small number of migrants, with a mean cumulative $\mathrm{FAD}=6$ between 4 and $5 \mathrm{Ma}$ in the tropics and a cumulative $\mathrm{FAD}=7$ in the temperate region. The land connection between the two continents occurred at the Isthmus of Panama, located within the tropical zone. Therefore, it would be expected that the Neotropics record the earliest GABI immigrants, but older immigrants have been found at higher latitudes.

The findings reported by Campbell and colleagues (Campbell et al., 2010; Frailey and Campbell, 2012; Prothero et al., 2014) in the Acre region of the Amazon basin, assigned to late Miocene ( $\sim 9 \mathrm{Ma}$ ) sediments would represent the oldest NA immigrants. However, the dromomerycine artiodactyl, peccaries, tapirs, and gomphotheres have not been found in other late Miocene localities in SA and these findings await further clarifications. In SA, the most frequent pre-GABI elements are procyonids recorded in several late Miocene-Pliocene (Huayquerian-Chapadmalalan) SA localities since $7.3 \mathrm{Ma}$ (Cione et al., 2007; Reguero and Candela, 2011; Forasiepi et al., 2014). The evidence of the fossil record combined with the living species distribution suggests that much of the evolutionary history of procyonids occurred in the Neotropics, possibly in SA (Eizirik, 2012). Molecular studies have predicted that the diversification of the group occurred in the early Miocene ( $\sim 20 \mathrm{Ma})$, with most of the major genus-level lineages occurring in the Miocene (Koepfli et al., 2007; Eizirik et al., 2010; Eizirik, 2012). This scenario requires a bias in the 
fossil record, claims an evolutionary history for procyonids in SA that largely precedes the GABI, and suggests an arrival into SA long before previously thought as for several other mammalian clades (Almendra and Rogers, 2012; and references therein).

Since $4 \mathrm{Ma}$, the number of FAD at higher latitudes rapidly increases and this trend continues during the Pleistocene. In contrast, the number of FAD in the tropics remains low during the Pliocene (cumulative FAD mean $=9$ by $2-3 \mathrm{Ma}$ ), but rapidly increases during the Pleistocene. A large difference in the number of $\mathrm{PBDB}$ collections across time and latitude is observed for land mammals for the last $12 \mathrm{Ma}$ (Figure 6B). Most records come from higher latitudes and are younger than $4 \mathrm{Ma}$, by the time the FAD increases; this suggest that temporal and geographic patterns of GABI are influenced by the sampling bias toward high latitudes and the higher number of Pliocene-Pleistocene records.

The migration of northern taxa into SA after the completion of the land bridge by $\sim 3 \mathrm{Ma}$ was correlated with supposed expansion of savannas and grasslands in the Neotropics during glacial periods (Webb, 1991, 2006; Leigh et al., 2014). The expansion of savannas during glacial times has been questioned (Behling et al., 2010). If this is the case, the Andes could have served as route of migration of northern taxa toward temperate environments in SA (Webb, 1991), as NA taxa seem to have been more successful in temperate biomes whereas SA taxa dominate in the tropics (Webb, 1991, 2006; Leigh et al., 2014).

\section{CONCLUSIONS}

The dissimilarity analysis primarily grouped the faunal assemblages by age and secondarily by geographic distribution. The dissimilarity values among the fossil faunal assemblages analyzed support the differentiation between tropical and temperate assemblages in SA during the middle Miocene (ColloncuranLaventan) and late Miocene (Huayquerian-Montehermosan). The mid-latitude, middle Miocene assemblage of Quebrada Honda has higher affinities with the slightly older and temperate Collón Curá than with the tropical assemblages of La Venta and Fitzcarrald. For the late Miocene, the temperate assemblages of Chiquimil, Andalhuala, Cerro Azul, and Monte Hermoso cluster together, while the Mesopotamian is between this group and the tropical assemblages of Acre and Urumaco.

The cumulative FAD across time and latitude shows that faunisitc movements related to GABI began during the late Miocene $(\sim 10 \mathrm{Ma})$ with the oldest records found at higher latitudes. The number of FAD remained relatively low until 4-5 Ma when FAD starts to increase, peaking during the Pleistocene.

The study of paleodiversity patterns and paleobiogeography in the Americas is challenged by the sampling bias toward higher latitudes and the still scarce data from tropical faunas. The interpretation of the temporal and geographic patterns of GABI is likely influenced by these sampling issues.

\section{AUTHOR CONTRIBUTIONS}

Conceived and designed: Juan D. Carrillo, Analía Forasiepi, Carlos Jaramillo, Marcelo R. Sánchez-Villagra. Compiled bibliographic data: Juan D. Carrillo, Analía Forasiepi F, Carlos Jaramillo. Analyzed data: Juan D. Carrillo, Carlos Jaramillo. Wrote the paper: Juan D. Carrillo, Analía Forasiepi. All authors contributed to the final interpretation and editing of the manuscript.

\section{ACKNOWLEDGMENTS}

We are grateful to V. Rull, and the topic editors T. Pennington and J. E. Richardson for the invitation to contribute to this volume and two anonymous reviews for the valuable comments. We thank A. A. Carlini, M. Bond, F. Prevosti, and the group of Evolutionary Morphology and Paleobiology of Vertebrates (Zurich), in particular G. Aguirre-Fernández and M. Stange, for valuable comments. A. Cardenas and J. Alroy contributed to the data available at the PBDB. Thanks go to Smithsonian Institution, The Anders Foundation, Gregory D. and Jennifer Walston Johnson, NSF OISE-EAR-DRL 0966884 and NSF EAR 0957679 and to A. A. Carlini and J. D. Carrillo-Briceño for the support during our work in Urumaco. We thank the authorities at the Instituto del Patrimonio Cultural of the República Bolivariana de Venezuela and the Alcaldía Municipio de Urumaco for their generous support. Juan Carrillo was supported by Swiss National Fund SNF 31003A-149605 to M. R. Sánchez-Villagra.

\section{SUPPLEMENTARY MATERIAL}

The Supplementary Material for this article can be found online at: http://www.frontiersin.org/journal/10.3389/fgene.2014. 00451/abstract

\section{REFERENCES}

Alberdi, M. T., Prado, J. L., and Salas, R. (2004). The Pleistocene Gomphotheriidae (Proboscidea) from Peru. Neues Jahrb. Geol. Paläont. Abh. 231, 423-452.

Almendra, A. L., and Rogers, D. S. (2012). "Biogeography of Central American mammals. Patterns and processes," in Bones, Clones and Biomes. The History and Geography of Recent Neotropical Mammals, eds B. D. Patterson and L. P. Costa (Chicago; London: The University of Chicago Press), 203-228. doi: 10.7208/chicago/9780226649214.003.0010

Alroy, J., (2013). North American Fossil Mammal Systematics. Paleobiology Database. Available online at: http://paleobiodb.org/cgibin/bridge.pl?page=OSA_3_North_American_mammals

Anaya, F., and MacFadden, B. J. (1995). Pliocene mammals from Inchasi, Bolivia: the endemic fauna just before the Great American Interchange. Bull. Fla. Mus. Nat. Hist. 39, 87-140.

Antoine, P. O., Marivaux, L., Croft, D. A., Billet, G., Ganerod, M., Jaramillo, C., et al. (2012). Middle Eocene rodents from Peruvian Amazonia reveal the pattern and timing of caviomorph origins and biogeography. Proc. Biol. Sci. 279, 1319-1326. doi: 10.1098/rspb.2011.1732

Antoine, P. O., Salas-Gismondi, R., Baby, P., Benammi, M., Brusset, S., De Franceschi, D., et al. (2007). The middle Miocene (Laventan) Fitzcarrald fauna, Amazonian Peru. Cuad. Museo Geominero 8, 19-24.

Baskin, J. A. (1989). Comments on New World Tertiary Procyonidae (Mammalia, Carnivora). J. Vertebr. Paleontol. 9, 110-117. doi: 10.1080/02724634.1989.10011743

Behling, H., Bush, M., and Hooghiemstra, H. (2010). "Biotic development of Quaternary Amazonia: a palynological perspective," in Amazonia: Landscape and Species Evolution (Chichester: Wiley-Blackwell Publishing Ltd.), 335-345.

Bondesio, P., Rabassa, J., Pascual, R., Vucetich, M. G., and Scillato-Yané, G. (1980). "La Formación Collón Curá de Pilcaniyeu viejo y sus alrededores (Río Negro, República Argentina). Su antigüedad y las condiciones ambientales según su distribución de litogénesis y sus vertebrados," in $2^{\circ}$ Congreso Argentino de Paleontología y Bioestratigrafía y $1^{\circ}$ Congreso Latinoamericano de Paleontología, Actas, Vol. 3 (Buenos Aires: Asociación Paleontológica Argentina), 85-99.

Bossi, G. E., Muruaga, C., Sanagua, J., Hernando, A., Quiroga, G., and Ahumada, A. (1993). "Geología y estratigrafía de la cuenca neógena Santa María-Hualfín (Dptos. Santa María y Belén), Provincia de Catamarca," in Actas, Congreso Geológico Argentino, 12th and Congreso de Exploración de Hidrocarburos, 2nd, Mendoza, Vol. 2 (Buenos Aires, Asociación Geológica Argentina), 156-165. 
Brandoni, D. (2013). "Los mamíferos continentales del "Mesopotamiense" (Mioceno tardío) de Entre Ríos, Argentina. Diversidad, edad y paleogeografía," in El Neógeno de la Mesopotamia argentina, Publicación especial 14, eds D. Brandoni and J. I. Noriega (Buenos Aires: Asociación Paleontológica Argentina), 179-191.

Brandoni, D., and Noriega, J. I. (2013). El neógeno de la Mesopotamia Argentina, Publicación Especial 14. Buenos Aires: Asociación Paleontológica Argentina.

Brunetto, E., Noriega, J. I., and Brandoni, D. (2013). "Sedimentología, estratigrafía y edad de la Formación Ituzaingó en la Provincia de Entre Ríos, Argentina," in El Neógeno de la Mesopotamia argentina, Publicación Especial, eds D. Brandoni, and J. I. Noriega (Buenos Aires, Argentina: Asociación Paleontológica Argentina), 13-27.

Campbell, K. E. Jr. (2004). The Paleogene Mammalian Fauna of Santa Rosa, Amazonian Peru. Los Angeles, CA: Natural History Museum of Los Angeles County.

Campbell, K. E. Jr., Frailey, C. D., and Romero-Pittman, L. (2000). The late Miocene Gomphothere Amahuacatherium Peruvium (Proboscidea: Gomphotheriidae) from Amazonian Peru: Implications for the Great American Faunal Interchange. Lima, Peri: Instituto Geologico Minero Metalurgico.

Campbell, K. E. Jr., Heizler, M., Frailey, C. D., Romero-Pittman, L., and Prothero, D. R. (2001). Upper Cenozoic chronostratigraphy of the southwestern Amazon Basin. Geology 29, 595-598. doi: 10.1130/0091-7613(2001)029<0595:UCCOTS $>2.0 . \mathrm{CO} ; 2$

Campbell, K. E. Jr., Prothero, D. R., Romero-Pittman, L., Hertel, F., and Rivera, N. (2010). Amazonian magnetostratigraphy: Dating the first pulse of the Great American Faunal Interchange. J. South Am. Earth Sci. 29, 619-626. doi: 10.1016/j.jsames.2009.11.007

Carlini, A. A., Brandoni, D., and Sánchez, R. (2006a). First Megatheriines (Xenarthra, Phyllophaga, Megatheriidae) from the Urumaco (Late Miocene) and Codore (Pliocene) Formations, Estado Falcón, Venezuela. J.Syst. Palaeontol. 4, 269-278. doi: 10.1017/S1477201906001878

Carlini, A. A., Brandoni, D., and Sánchez, R. (2008a). Additions to the knowledge of Urumaquia robusta (Xenarthra, Phyllophaga, Megatheriidae) from the Urumaco Formation (Late Miocene), Estado Falcón, Venezuela. Paläontol. Z. 82, 153-162. doi: 10.1007/BF02988406

Carlini, A. A., Scillato-Yané, G. J., and Sánchez, R. (2006b). New Mylodontoidea (Xenarthra, Phyllophaga) from the Middle Miocene-Pliocene of Venezuela. J. Syst. Palaeontol. 4, 255-267. doi: 10.1017/S147720190600191X

Carlini, A. A., Zurita, A., and Aguilera, O. A. (2008b). North American Glyptodontines (Xenarthra, Mammalia) in the Upper Pleistocene of northern South America. Paläontol. Z. 82, 125-138. doi: 10.1007/BF02988404

Carlini, A. A., Zurita, A., Scillato-Yané, G. J., Sánchez, R., and Aguilera, O. A. (2008c). New Glyptodont from the Codore Formation (Pliocene), Falcón State, Venezuela, its relationship with the Asterostemma problem, and the paleobiogeography of the Glyptodontinae. Paläontol. Z. 82, 139-152. doi: 10.1007/BF02988405

Castro, M. C., Carlini, A. A., Sánchez, R., and Sánchez-Villagra, M. R. (2014). A new Dasypodini armadillo (Xenarthra: Cingulata) from San Gregorio Formation, Pliocene of Venezuela: affinities and biogeographic interpretations. Naturwissenschaften 101, 77-86. doi: 10.1007/s00114-013-1131-5

Cione, A. L., Azpelicueta, M. D. L. M., Bond, M., Carlini, A. A., Casciotta, J. R., Cozzuol, M. A., et al. (2000). Miocene vertebrates from Entre Ríos province, eastern Argentina. Insugeo Ser. Correl. Geol. 14, 191-237.

Cione, A. L., and Tonni, E. P. (1996). Reassesment of the Pliocene-Pleistocene continental time scale of Southern South America. Correlation of the type Chapadmalalan with Bolivian sections. J. South Am. Earth Sci. 9, 221-236. doi: 10.1016/0895-9811(96)00008-9

Cione, A. L., and Tonni, E. P. (1999). "Biostratigraphy and chronological scale of upper-most Cenozoic in the Pampean area, Argentina," in Quaternary of South America and Antartic Peninsula, Vol. 3, eds J. Rabassa and M. Salemme (Rotterdam: Balkema), 23-51.

Cione, A. L., and Tonni, E. P. (2001). Correlation of Pliocene to Holocene southern south american and european vertebrate-bearing units. Boll. Soc. Paleontol. Ital. $40,167-173$.

Cione, A. L., Tonni, E. P., Bargo, S., Bond, M., Candela, A. M., Carlini, A. A., et al. (2007). "Mamíferos continentales del Mioceno tardío a la actualidad en la Argentina: cincuenta años de estudios," in Asociación Paleontológica Argentina, Publicación Especial 11 Ameghiana 50 aniversario (Buenos Aires: Asociación Paleontológica Argentina), 257-278.
Cody, S., Richardson, J. E., Rull, V., Ellis, C., and Pennington, T. (2010). The Great American Biotic Interchange revisited. Ecography 33, 326-332. doi: 10.1111/j. 1600-0587.2010.06327.x

Cozzuol, M. A. (2006). The Acre vertebrate fauna: Age, diversity, and geography. J. South Am. Earth Sci. 21, 185-203. doi: 10.1016/j.jsames.2006.03.005

Croft, D. A. (2007). The Middle Miocene (Laventan) Quebrada Honda fauna, southern Bolivia and a description of its Notoungulates. Palaeontology 50, 277-303. doi: 10.1111/j.1475-4983.2006.00610.x

Croft, D. A. (2012). "Punctuated isolation. The making and mixing of South American's mammals," in Bones, Clones and Biomes. The History and Geography of Recent Neotropical Mammals, eds B. D. Patterson and L. P. Costa (Chicago; London: The University of Chicago Press), 9-19.

Eizirik, E. (2012). "A molecular view on the evolutionary history and biogeography of Neotropical carnivores (Mammalia, Carnivora)," in Bones, Clones and Biomes. The History and Geography of Recent Neotropical Mammals, eds B. D. Patterson and L. P. Costa (Chicago; London: The University of Chicago Press), 123-142. doi: 10.7208/chicago/9780226649214.003.0007

Eizirik, E., Murphy, W. J., Koepfli, K. P., Johnson, W. E., Jerry, W., and Dragoo, J. W. (2010). Pattern and timing of diversification of the mammalian order Carnivora inferred from multiple nuclear gene sequences. Mol. Phylogenet. Evol. 56, 49-63. doi: 10.1016/j.ympev.2010.01.033

Flynn, J. J., and Swisher, C. C. III. (1995). "Cenozoic South American land mammal ages; correlation to global geochronologies," in Geochronology, Time Scales and Global Stratigraphic Correlation, eds W. Berggren, D. Kent, M. Aubry, and J. Herdenbol (Tulsa, OK: Soc. Sediment. Geol. Spec. Pub), 317-333.

Forasiepi, A. M., Soibelzon, L. H., Suarez-Gomez, C., Sánchez, R., Quiroz, L. I., Jaramillo, C., et al. (2014). Carnivorans at the Great American Biotic Interchange: new discoveries from the northern neotropics. Naturwissenschaffen 101, 965-974. doi: 10.1007/s00114-014-1237-4

Frailey, C. D., and Campbell, K. E. (2012). Two New Genera of Peccaries (Mammalia, Artiodactyla, Tayassuidae) from Upper Miocene Deposits of the Amazon Basin. J. Paleontol. 86, 852-877. doi: 10.1666/12-012.1

Garzione, C. N., Auerbach, D. J., Jin-Sook Smith, J., Rosario, J. J., Passey, B. H., Jordan, T. E., et al. (2014). Clumped isotope evidence for diachronous surface cooling of the Altiplano and pulsed surface uplift of the Central Andes. Earth Planet. Sci. Lett. 393, 173-181. doi: 10.1016/j.epsl.2014.02.029

Garzione, C. N., Hoke, G., Libarkin, J. C., Withers, S., MacFadden, B., Eiler, J., et al. (2008). Rise of the Andes. Science 320, 1304-1307. doi: 10.1126/science.1148615

Goin, F. J., Gelfo, J. N., Chornogubsky, L., Woodburne, M. O., and Martin, T. (2012). "Origins, radiations, and distributions of south american mammals," in Bones, Clones and Biomes. The History and Geography of Recent Neotropical Mammals, eds B. D. Patterson and L. P. Costa (Chicago; London: The University of Chicago Press), 20-50. doi: 10.7208/chicago/9780226649214. 003.0003

Goin, F. J., Montalvo, C. I., and Visconti, G. (2000). Los marsupiales (Mammalia) del Mioceno de la Formación Cerro Azul (Provincia de la Pampa, Argentina). Estudios Geol. 56, 101-126. doi: 10.3989/egeol.00561-2158

Herbst, R., Anzótegui, L. M., Esteban, G., Mautino, L. R., Morton, S., and Nasif, N. (2000). "Síntesis paleontológica del Mioceno de los valles Calchaquíes, noroeste argentino," in El Neógeno de Argentina, eds F. G. Aceñolaza and R. Herbst (Tucumán: INSUGEO, Serie Correlación Geológica), 263-288.

Hirschfeld, S. E., and Webb, S. D. (1968). Plio-Pleistocene megalonychid sloth of North America. Bull. Fla. State Mus. 12, 213-296.

Kay, R. F., and Madden, R. H. (1997a). Mammals and rainfall: paleoecology of the middle Miocene at La Venta (Colombia, South America). J. Human Evol. 32, 161-199. doi: 10.1006/jhev.1996.0104

Kay, R. F., and Madden, R. H. (1997b). "Paleogeography and paleoecology," in Vertebrate Paleontology in the Neotropics. The Miocene fauna of La Venta, Colombia, eds R. F. Kay, R. H. Madden, R. L. Cifelli, and J. J. Flynn (Washington; London: Smithsonian Institution Press), 520-550.

Kay, R. F., Madden, R. H., Cifelli, R. L., and Flynn, J. J. (1997). Vertebrate Paleontology in the Neotropics. The Miocene Fauna of La Venta, Colombia. Washington; London: Smithsonian Institution Press.

Koepfli, K. P., Gompper, M. E., Eizirik, E., Ho, C. C., Linden, L., and Maldonado, J. E. (2007). Phylogeny of the Procyonidae (Mammalia: Carnivora): molecules, morphology and the Great American Interchange. Mol. Phylogenet. Evol. 43, 1076-1095. doi: 10.1016/j.ympev.2006.10.003

Kramarz, A. G., Forasiepi, A. M., and Bond, M. (2011). "Vertebrados Cenozoicos," in Relatorio del XVIII Congreso Geológico Argentino. Geología y Recursos 
Naturales de la Provincia del Neuquén, eds H. A. Leanza, C. Arregui, O. Carbone, J. C. Danieli, and J. M. Vallés (Buenos Aires: Asociación Geológica Argentina), 557-572.

Latorre, C., Quade, J., and Mcintosh, W. C. (1997). The expansion of C4 grasses and global change in the late Miocene: Stable isotope evidence from the Americas. Earth Planet. Sci. Lett. 146, 83-96. doi: 10.1016/S0012-821X(96)00231-2

Latrubesse, E. M., Bocquentin, J., Santos, C. R., and Ramonell, C. G. (1997). Paleonvironmental model for the late Cenozoic southwestern Amazonia: paleontology and geology. Acta Amazonica 27, 103-118.

Leigh, E. G., O'Dea, A., and Vermeij, G. J. (2014). Historical biogeography of the Isthmus of Panama. Biol. Rev. 89, 148-172. doi: 10.1111/brv.12048

Linares, O. J. (2004). Bioestratigrafía de la fauna de mamíferos de las formaciones Socorro, Urumaco y Codore (Mioceno medio-Plioceno temprano) de la región de Urumaco, Falcón, Venezuela. Paleobiologia Neotropical 1, 1-26.

Lucas, S. G. (2013). The palaeobiogeography of South American gomphotheres. J. Palaeogeogr. 2, 19-40. doi: 10.3724/sp.j.1261.2013.00015

Lucas, S. G., and Alvarado, G. E. (2010). Fossil Proboscidea from the upper Cenozoic of Central America: taxonomy, evolutionary and paleobiogeographic significance. Revista Geológica de America Central 42, 9-42.

MacFadden, B. J. (2006). Extinct mammalian biodiversity of the ancient New World tropics. Trends Ecol. Evol. 21, 157-165. doi: 10.1016/j.tree.2005.12.003

MacFadden, B. J., Anaya, F., and Argollo, J. (1993). Magnetic polarity stratigraphy of Inchasi: a Pliocene mammal-bearing locality from the Bolivian Andes deposited just before the Great American Interchange. Earth and Planetary Science Letters 114, 229-241. doi: 10.1016/0012-821X(93) 90027-7

MacFadden, B. J., Anaya, F., Perez, H., Naeser, C. W., Zeitler, P. K., and Campbell Jr, K. E. (1990). Late Cenozoic Paleomagnetism and Chronology of Andean Basins of Bolivia: Evidence for Possible Oroclinal Bending. The Journal of Geology 98, 541-555. doi: 10.1086/629423

Madden, R. H., Guerrero, J., Kay, R. F., Flynn, J. J., Swisher, C. C., and Walton, A. H. (1997). "The Laventan stage and age," in Vertebrate paleontology in the Neotropics. The Miocene fauna of La Venta, Colombia, eds R. F. Kay, R. H. Madden, R. L. Cifelli and J. J. Flynn (Washington; Londonm: Smithsonian Instituion Press), 499-519.

Marshall, L. G., Pascual, R., Curtis, G. H., and Drake, R. E. (1977). South American Geochronology: Radiometric Time Scale for Middle to Late Tertiary MammalBearing Horizons in Patagonia. Science 195, 1325-1328. doi: 10.1126/science.195.4284.1325

Marshall, L. G., and Patterson, B. (1981). Geology and geochronology of the mammal-bearing Tertiary of the Valle de Santa Maria and Río Corral Quemado, Catamarca Province, Argentina. Fieldiana Geology 9, 1-80.

Marshall, L. G., Webb, S. D., Sepkoski, J. J., and Raup, D. M. (1982). Mammalian Evolution and the Great American Interchange. Science 215, 1351-1357. doi: $10.1126 /$ science.215.4538.1351

Mazzoni, M. M., and Benvenuto, A. (1990). Radiometric ages of Tertiary ignimbrites and the Collón Cura Formation, Northwestern Patagonia. in $9^{\circ}$ Congreso Geológico Argentino, Actas, Vol. 1 (Buenos Aires: Asociación Paleontológica Argentina), 731-746.

Montalvo, C. I., Melchor, R. N., Visconti, G., and Cerdeño, E. (2008). Vertebrate taphonomy in loess-palaeosol deposits: a case study from the late Miocene of central Argentina. Geobios 41, 133-143. doi: 10.1016/j.geobios.2006.09.004

Mora, A., Baby, P., Roddaz, M., Parra, M., Brusset, S., and Hermoza, W., et al. (2009). "Tectonic history of the andes and sub-andean zones: implications for the development of the Amazon drainage basin," in Amazonia: Landscape and Species Evolution (Wiley-Blackwell Publishing Ltd.), 38-60.

Morrone, J. J. (2014). Cladistic biogeography of the Neotropical region: identifying the main events in the diversification of the terrestrial biota. Cladistics 30, 202-214. doi: 10.1111/cla.12039

Negri, F. R., Bocquentin-Villanueva, J., Ferigolo, J., and Antoine, P.-O. (2010). "A review of tertiary mammal faunas and birds from Western Amazonia," in Amazonia: Landscape and Species Evolution (Chichester: Wiley-Blackwell Publishing Ltd.), 243-258.

Okasanen, J., Guillaume Blanchet, F., Kindt, R., Legendre, P., Minchin, P. R., and O'hara, R. B., et al. (2013). Vegan: Community Ecology Package. R package version 2.0-10. Available online at: http://CRAN.R-project.org/package=vegan

Pascual, R. (2006). Evolution and geography: The biogeographic history of south american land mammals. Ann. Mo. Bot. Gard. 93, 209-230. doi: 10.3417/00266493(2006)93[209:EAGTBH]2.0.CO;2
Patterson, B. D., and Costa, L. P. (2012). "Introduction to the history and geography of Neotropical mammals," in Bones, Clones and Biomes. The History and Geography of Recent Neotropical Mammals, eds B. D. Patterson and L. P. Costa (Chicago; London: The University of Chicago Press), 1-5. doi: 10.7208/chicago/9780226649214.003.0001

Patterson, B. D., Solari, S., and Velazco, P. M. (2012). "The role of the Andes in the diversification and biogeography of Neotropical mammals," in Bones, Clones and Biomes. The History and Geography of Recent Neotropical Mammals, eds B. D. Patterson, and L. P. Costa (Chicago; London: The University of Chicago Press), 351-378. doi: 10.7208/chicago/9780226649214. 003.0015

Pérez, L. M. (2013). "Nuevo aporte al conocimiento de la edad de la Formación Paraná, Mioceno de la Provincia de Entre Ríos, Argentina," in El Neógeno de la Mesopotamia Argentina, eds D. Brandoni and J. I. Noriega (Buenos Aires: Asociación Paleontológica Argentina, Publicación Especial), 7-12.

Prevosti, F., Forasiepi, A., and Zimicz, N. (2013). The evolution of the cenozoic terrestrial mammalian predator guild in South America: competition or replacement? J. Mammal. Evol. 20, 3-21. doi: 10.1007/s10914-011-9175-9

Prevosti, F. J. (2006). New material of Pleistocene cats (Carnivora, Felidae) from Southern South America, with comments on biogeography and the fossil record. Geobios 39, 679-694. doi: 10.1016/j.geobios.2005.01.004

Prevosti, F. J., and Pardiñas, U. F. J. (2009). Comment on "The oldest South American Cricetidae (Rodentia) and Mustelidae (Carnivora): late Miocene faunal turnover in central Argentina and the Great American Biotic Interchange" by D. H. Verzi and C. I. Montalvo [Palaeogeography, Palaeoclimatology, Palaeoecology 267 (2008) 284-291]. Palaeogeogr. Palaeoclimatol. Palaeoecol. 280, 543-547. doi: 10.1016/j.palaeo.2009.05.021

Prothero, D. R., Campbell, K. E., Beatty, B. L., and Frailey, C. D. (2014). New late Miocene dromomerycine artiodactyl from the Amazon Basin: implications for interchange dynamics. J. Paleontol. 88, 434-443. doi: 10.1666/13-022

Quiroz, L. I., and Jaramillo, C. A. (2010). "Stratigraphy and sedimentary environments of Miocene shallow to marginal marine deposits in the Urumaco trough, Falcón basin, western Venezuela," in Urumaco and Venezuelan Paleontology. The Fossil Record of the Northern Neotropics, eds M. R. Sánchez-Villagra, O. A. Aguilera, and A. A. Carlini (Bloomington; Indianapolis: Indiana University Press), 153-172.

Rabassa, J. (1974). Geología de la Región Pilcaniyeu-Comallo. Bariloche: Fundación Bariloche, Departamento Recursos Naturales Energéticos, Publicación.

Rabassa, J. (1978). "Estratigrafía de la región Pilcaniyeu-Comallo, provincia de Río Negro," in $7^{\circ}$ Congreso Geológico Argentino, Actas, Vol. 1 (Neuquén), 731-746.

Ramos, V. (1999). Plate tectonic setting of the Andean Cordillera. Episodes 22, $183-190$.

R Core Team. (2013). R: A Language and Environment for Statistical Computing. Vienna, Austria: R Foundation for Statistical Computing. Available online at: http://www.R-project.org/.

Reguero, M. A., and Candela, A. M. (2011). "Late Cenozoic mammals from the Northwest of Argentina," in Cenozoic geology of the Central Andes of Argentina, eds. J. A. Salfity and R. A. Marquillas (Salta: INCE, Instituto del Cenozoico), 411-426.

Reguero, M. A., Candela, A. M., and Alonso, R. N. (2007). Biochronology and biostratigraphy of the Uquía Formation (Pliocene-early Pleistocene, NW Argentina) and its significance in the Great American Biotic Interchange. J. South Am. Earth Sci. 23, 1-16. doi: 10.1016/j.jsames.2006.09.005

Ribeiro, A. M., Madden, R. H., Negri, F. R., Kerber, L., Hsiou, A. S., and Rodrigues, K. A. (2013). "Mamíferos fósiles y biocronología en el suroeste de la Amazonia, Brasil," in El Neógeno de la Mesopotamia Argentina, Publicación Especial 14, eds D. Brandoni and J. I. Noriega (Buenos Aires: Asociación Paleontológica Argentina), 207-221.

Riggs, E., and Patterson, B. (1939). Stratigraphy of late Miocene and Pliocene deposits of the Province of Catamarca (Argentina) with notes on the faunae. Physics 14, 143-162.

Sánchez-Villagra, M. R., Aguilera, O. A., and Carlini, A. A. (2010). Urumaco \& Venezuelan Paleontology. The fossil record of the Northern Neotropics. Bloomington; Indianapolis: Indiana University Press.

Scheyer, T. M., Aguilera, O. A., Delfino, M., Fortier, D. C., Carlini, A. A., Sanchez, R., et al. (2013). Crocodylian diversity peak and extinction in the late Cenozoic of the northern Neotropics. Nat. Commun. 4, 1907. doi: 10.1038/ncomms2940

Simpson, G. G. (1980). Splendid Isolation. The Curious History of South American Mammals. New Haven; London: Yale University Press. 
Tejada-Lara, J. V., Salas-Gismondi, R., Pujos, F., Baby, P., Benammi, M., Brusset, S., et al. (in press). Life in proto-Amazonia: middle Miocene mammals from the Fitzcarrald Arch (Peruvian Amazonia). Paleontology.

Tews, J., Brose, U., Grimm, V., Tielbörger, K., Wichmann, M. C., Schwager, M., et al. (2004). Animal species diversity driven by habitat heterogeneity/diversity: the importance of key stone structures. J. Biogeogr. 31, 79-92. doi: 10.1046/j.03050270.2003.00994.x

Tomassini, R. L., and Montalvo, C. I. (2013). Taphonomic modes on fluvial deposits of the Monte Hermoso Formation (early Pliocene), Buenos Aires province, Argentina. Palaeogeogr. Palaeoclimatol. Palaeoecol. 369, 282-294. doi: 10.1016/j.palaeo.2012.10.035

Tomassini, R. L., Montalvo, C. I., Deschamps, C. M., and Manera, T. (2013). Biostratigraphy and biochronology of the Monte Hermoso Formation (early Pliocene) at its type locality, Buenos Aires Province, Argentina. J. South Am. Earth Sci. 48, 31-42. doi: 10.1016/j.jsames.2013.08.002

Verzi, D. H., and Montalvo, C. I. (2008). The oldest South American Cricetidae (Rodentia) and Mustelidae (Carnivora): late Miocene faunal turnover in central Argentina and the Great American Biotic Interchange. Palaeogeogr. Palaeoclimatol. Palaeoecol. 267, 284-291. doi: 10.1016/j.palaeo.2008. 07.003

Verzi, D. H., Vieytes, E. C., and Montalvo, C. I. (2011). Dental evolution in neophanomys (Rodentia, Octodontidae) from the late Miocene of central Argentina. Geobios 44, 621-633. doi: 10.1016/j.geobios.2011.02.008

Vrba, E. S. (1992). Mammals as a key to evolutionary theory. J. Mammal. 73, 1-28. doi: $10.2307 / 1381862$

Webb, S. D. (1976). Mammalian Faunal Dynamics of the Great American Interchange. Paleobiology 2, 220-234.

Webb, S. D. (1985). "Late Cenozoic mammal dispersal between the Americas," in The Great American Biotic Interchange, eds F. G. Stehli and S. D. Webb (New York; London: Plenum Press), 357-386. doi: 10.1007/978-1-4684-9181-4_14
Webb, S. D. (1989). "Osteology and relationships of Thinobadistes segnis, the first Mylodont sloth in North America," in Advances in Tropical Mammalogy, eds K. H. Redford and J. F. Eisenberg (Gainsville: The Sandhill Crane Press), 469-532.

Webb, S. D. (1991). Ecogeography and the Great American Interchange. Paleobiology 17, 266-280.

Webb, S. D. (2006). The Great American Biotic Iinterchange: patterns and processes. Ann. Mo. Bot. Gard. 93, 245-257. doi: 10.3417/0026-6493(2006)93[245: TGABIP]2.0.CO;2

Woodburne, M. (2010). The Great American Biotic Interchange: dispersals, tectonics, climate, sea level and holding pens. J. Mammal. Evol. 17, 245-264. doi: 10.1007/s10914-010-9144-8

Conflict of Interest Statement: The authors declare that the research was conducted in the absence of any commercial or financial relationships that could be construed as a potential conflict of interest.

Received: 30 August 2014; accepted: 10 December 2014; published online: 05 January 2015.

Citation: Carrillo JD, Forasiepi A, Jaramillo C and Sánchez-Villagra MR (2015) Neotropical mammal diversity and the Great American Biotic Interchange: spatial and temporal variation in South America's fossil record. Front. Genet. 5:451. doi: 10.3389/ fgene.2014.00451

This article was submitted to Evolutionary and Population Genetics, a section of the journal Frontiers in Genetics.

Copyright (c) 2015 Carrillo, Forasiepi, Jaramillo and Sánchez-Villagra. This is an open-access article distributed under the terms of the Creative Commons Attribution License (CC BY). The use, distribution or reproduction in other forums is permitted, provided the original author(s) or licensor are credited and that the original publication in this journal is cited, in accordance with accepted academic practice. No use, distribution or reproduction is permitted which does not comply with these terms. 